\title{
Mathematical Modelling And Simulation of CH3NH3Pb(I1-XbrX)3 Based Perovskite Solar Cells For High Efficiency
}

\section{Divya Sharma ( $\nabla$ divya13jan@gmail.com )}

National Institute of Technical Teachers' Training and Research Chandigarh

\section{Rajesh Mehra}

National Institute of Technical Teachers' Training and Research Chandigarh

\section{Balwinder Raj}

National Institute of Technical Teachers' Training and Research Chandigarh

\section{Research Article}

Keywords: Mixed Halide PSCs, Perovskite Layer (Active/ absorber layer), SCAPS 1-D, Hole Transport Layer (HTL), Electron Transport Layer (ETL).

Posted Date: January 4th, 2022

DOI: https://doi.org/10.21203/rs.3.rs-1133949/v1

License: (9) This work is licensed under a Creative Commons Attribution 4.0 International License. Read Full License 


\title{
Mathematical Modelling And Simulation Of $\mathrm{CH}_{3} \mathrm{NH}_{3} \mathrm{~Pb}\left(\mathrm{I}_{1-x b r}\right)_{3}$ Based Perovskite Solar Cells For High Efficiency
}

\author{
Divya Sharma, Rajesh Mehra and Balwinder Raj \\ Department of Electronics and Communications Engineering, \\ NITTTR Chandigarh, India-160019, Email ID: divya13jan@gmail.com; \\ rajeshmehra@nitttrchd.ac.in, balwinderraj@gmail.com
}

\begin{abstract}
Mathematical modelling can offer the physical intuitions about the charge transport process inside a solar cells and provide the various elements affecting their performance. In the present paper, $\left(\mathrm{CH}_{3} \mathrm{NH}_{3} \mathrm{~Pb}\left(\mathrm{I}_{1-\mathrm{x}} \mathrm{Br}_{\mathrm{x}}\right)_{3}\right.$ based various perovskite solar cells have been mathematically simulated deploying SCAPS simulator. Various Hole Transport layers (HTLs) based on thickness, total defect density and donor density of mixed halide perovskite have been compared using $\mathrm{Cd}_{1-\mathrm{x}} \mathrm{Zn}_{\mathrm{x}} \mathrm{S}$ as an Electron Transport Layer (ETL). Amongst the proffered HTLs, P3HT [Poly(3-hexylthiophene)] executed better and exhibited the PCE of $28.28 \%$. During the simulation, mixed halide perovskite layer with thickness of $700 \mathrm{~nm}$ has been found suitable for the effective solar cell design. These mathematically simulated outcomes indicate the optimum efficiency of the solar cell that may further be prompted to design the extremely high efficient solar cells.
\end{abstract}

Keywords: Mixed Halide PSCs, Perovskite Layer (Active/ absorber layer), SCAPS 1-D, Hole Transport Layer (HTL), Electron Transport Layer (ETL).

\section{INTRODUCTION}

The exploitation of energy has been escalated enormously. Thus, betting on conventional energy resources should not be the only criteria to fulfil the expanding energy requirement. Solar cells exhibiting improved efficiency are desirable contender to fulfil the essential electrical energy demand in order to produce maximum electric power as output, exploiting solar energy as input. In this regard, Perovskite solar cells (PSCs) are the one of the most optimistic participant because of their exceptional power conversion capabilities in addition to improved light absorption, lesser electron-hole binding energy, direct band gap and inexpensive fabrication in moderate conditions. A viable PSC must have exaggerated magnitude of FF, $\mathrm{J}_{\mathrm{SC}}, \mathrm{V}_{\mathrm{OC}}$ and PCE for converting ample amount of solar energy to electrical energy using photovoltaic effect. For this, a standard PSC has versatile configuration consisting of a Perovskite Layer (Active/ absorber layer), Hole Transport Layer (HTL) and Electron Transport Layer (ETL). Practically, it is an expensive and time consuming task to fabricate various layers of a multi-layered PSC. Therefore, computational modelling and simulation studies are first and foremost steps to follow prior actual fabrication of different layers of PSC as these are helpful in identifying appropriate materials required for processing different layers of PSCs.

An absorber layer of a PSC incorporates perovskite structure having general formula $\mathrm{CDX}_{3}$ where $\mathrm{C}$ denotes organic cation $\mathrm{viz}$ formamidinium $\left(\mathrm{NH}=\mathrm{CHNH}_{3}{ }^{+}\right)$or methyl ammonium $\left(\mathrm{CH}_{3} \mathrm{NH}_{3}{ }^{+}\right)$, D denotes inorganic cation viz $\mathrm{Sn}^{2+}$ and $\mathrm{Pb}^{2+}$ and $\mathrm{X}$ denotes halide ion viz $\mathrm{Cl}^{-}, \mathrm{Br}^{-}$ or $\mathrm{I}^{-}$. Methyl ammonium lead iodide $\left(\mathrm{MAPbI}_{3}\right)$ is the most common perovskites used in PSCs while $\mathrm{MAPbI}_{3-\mathrm{x}} \mathrm{Cl}_{\mathrm{x}}, \mathrm{MAPb}\left(\mathrm{I}_{1-\mathrm{x}} \mathrm{Br}_{\mathrm{x}}\right)_{3}, \mathrm{MAPbSnI}_{3}, \mathrm{MAPbI}_{3}, \mathrm{FASnI}_{3}$ are the other perovskite materials used as absorber layers for constitution of perovskite solar cell [1-5]. Various perovskites \& non perovskites material are also examined \& numerically simulates for further utilization as active absorber material in multilayer PSC. In addition, pure organic perovskite materials have also been explored \& found suitable for absorber layer in PSCs. 
Performance of the perovskite layer can be improved by utilization of an appropriate ETM which withdraws the photoelectron produced by the absorber material \& the HTM which promotes the formation of holes. $\mathrm{TiO}_{2}, \mathrm{ZnO}, \mathrm{CdZnS}$ and $\mathrm{SnO}_{2}$ are the materials used as ETLs [6-10] while $\mathrm{CuI}, \mathrm{CuO}, \mathrm{P} 3 \mathrm{HT}$, Spiro-OMeTAD, $\mathrm{Cu}_{2} \mathrm{O}, \mathrm{CuSCN}_{\mathrm{CuSbS}}$ are the materials used as HTLs [11-13]. The stability \& efficiency of perovskite solar cells are eminently relying on characteristics \& genre of these layers. It has been observed that PSC exhibits maximum efficiency when rutile crystalline phase of $\mathrm{TiO}_{2}$ is used as ETM. This phase of $\mathrm{TiO}_{2}$ requires high annealing temperature for processing which restricts its use in perovskite solar cells. In the same way, most common HTMs viz PEDOT:PSS \& SpiroMeTOD are expensive \& less stable, which restricts their use in perovskite solar cells. Hence, various researches on the optimization of solar cell performance by using different ETM \& HTMs have been carried out. A perovskite solar cell exhibits an efficiency of $24.32 \%$ while using MASnI3, TiO2 \& CuSCN as absorber layer, ETM \& HTM respectively. Other perovskite solar cells exhibits efficiency of $24.17 \%, 24.50 \%$ \& $25.36 \%$ while using MASnI3 as absorber materials, $\mathrm{ZnO}$ as ETM, \& SpiroMeTOD, PEDOT:PSS, \& $\mathrm{Cu}_{2} \mathrm{O}$ as HTMs respectively. However, perovskite solar cell with $\mathrm{CuI}$ as HTM, ZnO as ETM \& MASnI3 as perovskite layer exhibits as efficiency of $24.82 \%$. The influence of back contact material is also studied on efficiency of PSC. Remarkably, perovskite solar cells that came into existence in 2009 exhibited efficiency of $3.8 \%$ which further have been enhanced to $25.6 \%$ in 2021[14-17]. Their efficiencies are still on progressive phase with an unpredictable upper threshold.

In this paper, the $\mathrm{CH}_{3} \mathrm{NH}_{3} \mathrm{PbI}_{3-\mathrm{x}} \mathrm{Cl}_{\mathrm{x}}$ based perovskite solar cell (existing) with $\mathrm{Cd}_{1-\mathrm{x}} \mathrm{Zn}_{\mathrm{x}} \mathrm{S}$ and $\mathrm{CuI}$ as ETL and HTL respectively, exhibiting efficiency of $25.68 \%$, are compared with various $\left(\mathrm{CH}_{3} \mathrm{NH}_{3} \mathrm{~Pb}\left(\mathrm{I}_{1-\mathrm{x}} \mathrm{Br}_{\mathrm{x}}\right)_{3}\right.$ based perovskite solar cells that have been mathematically simulated deploying SCAPS simulator where different $\mathrm{HTLs}$ viz $\mathrm{Cu}_{2} \mathrm{O}, \mathrm{CuSbS}_{2}, \mathrm{CuO}$ and P3HT [Poly(3-hexylthiophene)] (proposed) are used separately using $\mathrm{Cd}_{1-\mathrm{x}} \mathrm{Zn}_{\mathrm{x}} \mathrm{S}$ as an ETL. Amongst the abovementioned proposed perovskite solar cells, cell with P3HT [Poly(3hexylthiophene)] as HTL executed better and exhibited the PCE of 28.28\%. Interestingly, $\mathrm{P} 3 \mathrm{HT}$ is an organic material and is cheaper than the other organic HTL SpiroMeOTAD.

\section{PROPOSED DEVICE SIMULATION}

In this paper, design simulation in respect of the mixed halide perovskite solar cells has been executed on SCAPS 1D software. The device design figured for the simulation is glass/ TCO/ $\mathrm{Cd}_{1-\mathrm{x}} \mathrm{Zn}_{\mathrm{x}} \mathrm{S}$ (buffer layer or ETL)/ DL I/ active layer $\left(\mathrm{CH}_{3} \mathrm{NH}_{3} \mathrm{~Pb}\left(\mathrm{I}_{1-\mathrm{x}} \mathrm{Br}_{\mathrm{x}}\right)_{3}\right) / \mathrm{DL}$ II/ HTL/ back contact. The proposed cell has been simulated independently using various HTLs viz CuI, $\mathrm{Cu}_{2} \mathrm{O}, \mathrm{CuSbS}_{2}, \mathrm{CuO}$ and $\mathrm{P} 3 \mathrm{HT}$. From the discrete simulations, it is found that solar cell with P3HT as HTL has displayed maximum efficiency of $28.28 \%$. A simple configuration with respect to this is revealed in Fig. 1(a). SCAPS 1D software used for the simulation is administered by Poisson and Continuity equation.

$$
\begin{aligned}
& D n \frac{\partial^{2} n(x)}{\partial x^{2}}+\mu E_{n}(x) \frac{\partial n(x)}{\partial x}+G_{n}(x)-R_{n}(x)=0 \\
& D p \frac{\partial^{2} p(x)}{\partial x^{2}}-\mu E_{p}(x) \frac{\partial n(x)}{\partial x}+G_{p}(x)-R_{p}(x)=0
\end{aligned}
$$

where $\mathrm{n}(\mathrm{x})$ and $\mathrm{p}(\mathrm{x})$ denotes concentration of negative and positive charge carriers respectively; $G_{n}(x)$ and $G_{p}(x)$ denotes rate of photogeneration; and $R_{n}(x)$ and $R_{p}(x)$ signify 
the recombination of negative and positive charge carriers, respectively. $\mathrm{E}(\mathrm{x}), \mathrm{D}$ and $\mu$ in Eqs. 1 and 2 denotes electric field inside perovskite layer, diffusion constant and carrier mobility respectively [18]. A systematic model is established within the perovskite layer followed by calculation of respective values for the parameters using Poisson and Continuity equation. The leading parameters of individual layers are tabulated in Table 1.

The defects existing in the device structure highly influence the performance of cell. Shockley-Read-Hall (SRH) recombination model applicable to regulate the defect concentration in a solar cell is mathematically expressed as [19-20]-

$$
R=\frac{\tau_{n, p}^{-1}\left(n p-n_{i}^{2}\right)}{n+p+2_{n i} \cosh \left(\frac{E_{t}-E_{i}}{k T}\right)}
$$

where, $\tau_{\mathrm{n}, \mathrm{p}}=$ the relaxation time of charge carriers

$$
\begin{aligned}
& n, p=\text { density of electron and hole respectively } \\
& n_{i}=\text { intrinsic density } \\
& E_{i}=\text { intrinsic energy level } \\
& E_{t}=\text { energy level of the trap defects }
\end{aligned}
$$

Thermal velocity for negative and positive charge carriers in every layer is held steady at $10^{7}$ $\mathrm{cm} / \mathrm{s}$.

$$
\tau_{n, p}=\frac{1}{\sigma_{n, p} v_{t h} N_{t}}
$$

$\tau_{n, p}$ shown in Eq. 4 represents the relaxation time of negative and positive moving charged particles. $\mathrm{N}_{\mathrm{t}}$, and $\sigma_{\mathrm{n}, \mathrm{p}}$ are density and captured area of cross-section pertaining to defects, respectively.

Diffusion length $(l)$ in respect of mobile charged particles is expressed as -

$$
l=\sqrt{D \tau}
$$

Here, it is the diffusion constant that is represented by $\mathrm{D}$ which can be find using below mentioned relation

$$
D=\frac{\mu k T}{q}
$$

Various parameters can be estimated using above cited equations. The calculated values are found to be much closer to the simulated results.

The planned design of solar cell for the simulation is shown in Fig. 1(b). In addition, the band diagram (Energy diagram) in respect of planned cell configuration is shown in Fig. 2.

The absorption coefficient $(\alpha)$ can be estimated by- 


$$
\alpha=A_{\alpha}(h v-E g)^{1 / 2}
$$

where $\mathrm{A}_{\alpha}$ is $10^{5}$.

Table 1. shows the optimized parameters which is further analysed to construct an effective Perovskite solar cell.

\begin{tabular}{|c|}
\hline Metal Back Contact \\
\hline HTL $\left(\mathrm{P} 3 \mathrm{HT}, \mathrm{Cu}_{2} \mathrm{O}, \mathrm{CuSbS}_{2}, \mathrm{CuO}\right)$ \\
\hline Absorber Layer $\mathrm{CH}_{3} \mathrm{NH}_{3} \mathrm{~Pb}\left(\mathrm{I}_{1-\mathrm{x}} \mathrm{Br}\right)_{3}$ \\
\hline $\mathrm{ETL}\left(\mathrm{Cd}_{1-\mathrm{x}} \mathrm{Zn}_{\mathrm{x}} \mathrm{S}\right)$ \\
\hline Transparent Conducting Oxide \\
\hline Glass Substrate \\
\hline
\end{tabular}

(a)

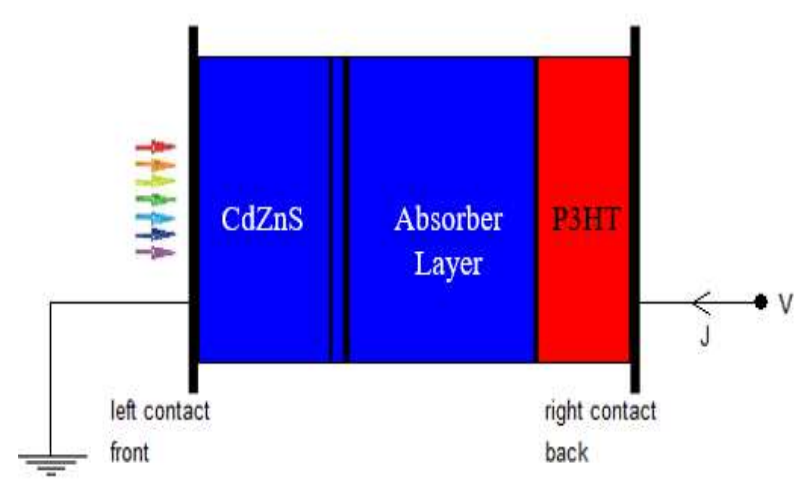

(b)

Fig. 1. (a) Block diagram of perovskite solar cell (b) Simulated device structure.

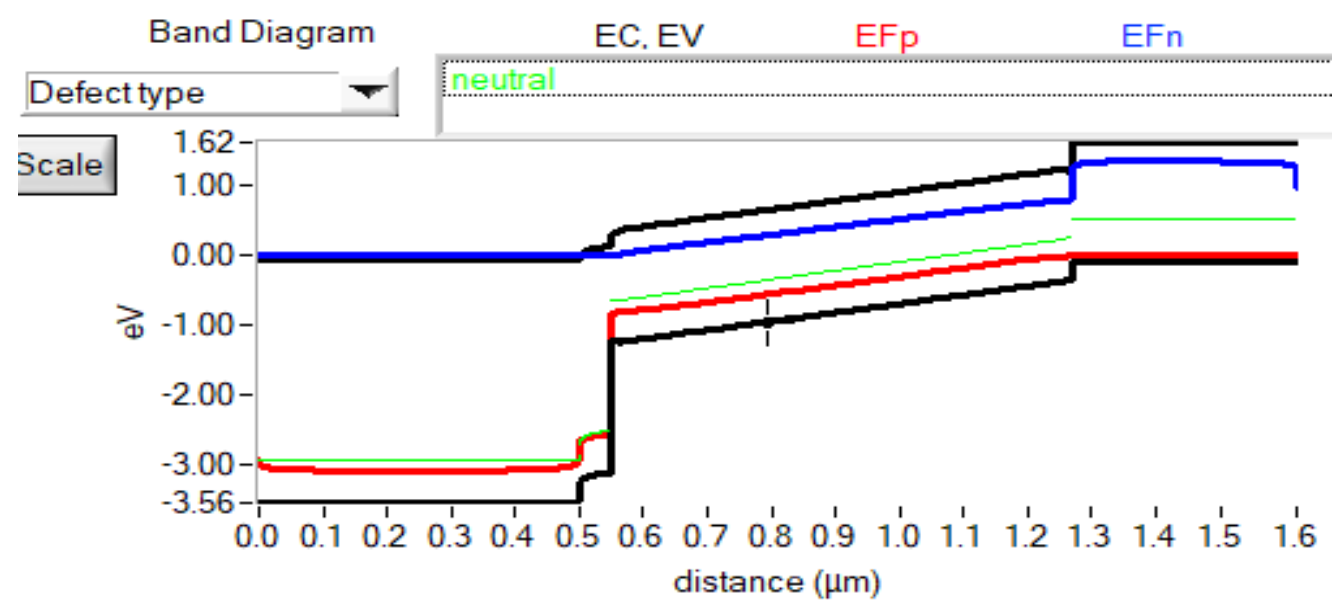

Fig. 2. Energy Band Diagram

Table 1 Design Simulation Parameters

\begin{tabular}{|l|l|l|l|l|l|l|l|l|l|}
\hline Parameters & $\begin{array}{l}\text { TCO } \\
\left(\mathrm{SnO}_{2}: \mathrm{F}\right) \\
{[21]}\end{array}$ & $\begin{array}{l}\text { ETM } \\
\left(\mathrm{Cd}_{1-}\right. \\
\left.\mathrm{ZZ}_{\mathrm{x}} \mathrm{S}\right) \\
{[21]}\end{array}$ & $\begin{array}{l}\text { IDL I } \\
{[21]}\end{array}$ & $\begin{array}{l}\text { Absorber } \\
\text { Layer } \\
\left(\mathrm{CH}_{3} \mathrm{NH}_{3} \mathrm{~Pb}\left(\mathrm{I}_{1-}\right.\right.\end{array}$ & $\begin{array}{l}\text { IDL II } \\
{[21]}\end{array}$ & $\begin{array}{l}\text { HTM } \\
(\mathrm{P3HT}) \\
{[23]}\end{array}$ & $\begin{array}{l}\mathrm{HTM} \\
\left(\mathrm{Cu}_{2} \mathrm{O}\right) \\
{[24]}\end{array}$ & $\begin{array}{l}\text { HTM } \\
(\mathrm{CuSbS}) \\
{[25]}\end{array}$ & $\begin{array}{l}\text { HTM } \\
(\mathrm{CuO}) \\
{[23]}\end{array}$ \\
\hline Thickness $(\mathrm{nm})$ & 500 & 50 & 10 & 700 & 10 & 350 & 350 & 350 & 350 \\
\hline $\begin{array}{l}\text { Band gap E } \\
(\mathrm{eV})\end{array}$ & 3.5 & 3.25 & 1.55 & 1.61 & 1.55 & 1.7 & 2.17 & 1.58 & 1.5 \\
\hline $\begin{array}{l}\text { Electron } \\
\text { Affinity }(\mathrm{eV})\end{array}$ & 4 & 4.08 & 3.9 & 3.86 & 3.9 & 3.5 & 3.2 & 4.2 & 4.07 \\
\hline
\end{tabular}




\begin{tabular}{|c|c|c|c|c|c|c|c|c|c|}
\hline $\begin{array}{l}\text { Relative } \\
\text { Permittivity }\left(\varepsilon_{\mathrm{r}}\right)\end{array}$ & 9 & 9 & 6.5 & 6.5 & 6.5 & 3 & 7.5 & 14.6 & 18.1 \\
\hline $\begin{array}{l}\text { Effective } \\
\text { Conduction } \\
\text { Band Density, } \\
\mathrm{N}_{\mathrm{C}}\left(\mathrm{cm}^{-3}\right)\end{array}$ & $2.2 \times 10^{18}$ & $2.2 \times 10^{18}$ & $2.2 \times 10^{18}$ & $2.2 \times 10^{18}$ & $2.2 \times 10^{18}$ & $2 \times 10^{18}$ & $2 \times 10^{18}$ & $2 \times 10^{18}$ & $2.2 \times 10^{19}$ \\
\hline $\begin{array}{l}\text { Effective } \\
\text { Valence Band } \\
\text { Density }\left(\mathrm{cm}^{-3}\right)\end{array}$ & $1.8 \times 10^{18}$ & $1.8 \times 10^{18}$ & $1.8 \times 10^{18}$ & $1.8 \times 10^{19}$ & $1.8 \times 10^{18}$ & $2 \times 10^{19}$ & $1.8 \times 10^{18}$ & $1 \times 10^{19}$ & $5.5 \times 10^{20}$ \\
\hline $\begin{array}{l}\text { Electron/Hole } \\
\text { thermal } \\
\text { velocity }\left(\mathrm{cms}^{-1}\right)\end{array}$ & $1 \times 10^{7}$ & $1 \times 10^{7}$ & $1 \times 10^{7}$ & $1 \times 10^{7}$ & $1 \times 10^{7}$ & $1 \times 10^{7}$ & $1 \times 10^{7}$ & $1 \times 10^{7}$ & $1 \times 10^{7}$ \\
\hline $\begin{array}{l}\text { Electron/Hole } \\
\text { Mobility, } \mu_{\mathrm{n}} / \mu_{\mathrm{p}} \\
\left(\mathrm{cm}^{2} \mathrm{~V}^{-1} \mathrm{~s}^{-1}\right)\end{array}$ & $20 / 10$ & $340 / 50$ & $2 / 2$ & $2 / 2$ & $2 / 2$ & $\begin{array}{l}1.8 \times 10^{-} \\
3 / \\
1.8 \times 10^{-2}\end{array}$ & $20 / 80$ & 49/49 & $\begin{array}{l}1 \times 10^{2} / \\
1 \times 10^{-1}\end{array}$ \\
\hline $\begin{array}{l}\text { Donor/Acceptor } \\
\text { Concentration, } \\
\mathrm{N}_{\mathrm{D}} / \mathrm{N}_{\mathrm{A}}\left(\mathrm{cm}^{-3}\right)\end{array}$ & $2 \times 10^{19}$ & $1 \times 10^{16}$ & $10^{13}$ & $10^{13}$ & $10^{13}$ & $10^{18}$ & $10^{18}$ & $1.38 \times 10^{18}$ & $10^{15}$ \\
\hline $\begin{array}{l}\text { Defect Density, } \\
\mathrm{N}_{\mathrm{t}}\left(\mathrm{cm}^{-3}\right)\end{array}$ & $10^{15}$ & $10^{18}$ & $10^{10}$ & $2.5 \times 10^{12}$ & $10^{10}$ & $10^{14}$ & $10^{14}$ & $10^{14}$ & $10^{13}$ \\
\hline
\end{tabular}

\section{RESULTS AND DISCUSSIONS}

\section{Effect of Thickness of Mixed Halide Perovskite Layer}

In this paper, mixed halide perovskite layers have been analysed with varying thickness from $300 \mathrm{~nm}$ to $1300 \mathrm{~nm}$. It has been observed that thin perovskite layers lead to lower current density $\left(\mathrm{J}_{\mathrm{sc}}\right)$ and lower efficiency $(\eta)$ values due to meagre light absorption which is not advantageous for a solar cell. On the other side, perovskite layers with higher thickness results in higher recombination due to instigation of a critical path for the movement of electrons and holes. Consequently, it is necessary to select a perovskite layer of optimum thickness to design an efficient solar cell. Experimentally, it has been found that mixed halide perovskite shows optimum efficiency between thickness range 400-800 $\mathrm{nm}$. The existing perovskite cell with $\mathrm{CH}_{3} \mathrm{NH}_{3} \mathrm{PbI}_{3-\mathrm{x}} \mathrm{Cl}_{\mathrm{x}}$ as perovskite layer at $330 \mathrm{~nm}$ thickness exhibits the $\mathrm{PCE}$ of $25.68 \%$ [21]. Utilizing $\mathrm{CH}_{3} \mathrm{NH}_{3} \mathrm{~Pb}_{(}\left(\mathrm{I}_{1-\mathrm{x}} \mathrm{Br}_{\mathrm{x}}\right)_{3}$, against existing $\mathrm{CH}_{3} \mathrm{NH}_{3} \mathrm{PbI}_{3-\mathrm{x}} \mathrm{Cl}_{\mathrm{x}}$, as a perovskite layer with a thickness of $700 \mathrm{~nm}$, the proposed device has exhibited the optimum PCE of $28.28 \%$ corresponding to $\mathrm{VOC}_{\mathrm{OC}}=1.4207 \mathrm{~V}, \mathrm{~J}_{\mathrm{SC}}=23.472 \mathrm{~mA} / \mathrm{cm}^{2}$, $\mathrm{FF}=84.80 \%$ is tabulated in Table 2 . The performance begins to fall gradually after that due to escalated rate of recombination. Due to the variation within diffusion length and absorption depth of mobile charged particles, they recombine prior reaching to the interface. Consequently, these is steady decline in $\mathrm{V}_{\mathrm{oc}}$ and FF values along with decrease in PCE as shown in Fig.3.

Table 2 Comparison between existing device and proposed device

\begin{tabular}{|c|l|c|c|}
\hline Sr. No. & Parameters & Existing Device [21] & Proposed Device \\
\hline 1 & Solar Cell Efficiency (PCE), $\eta(\%)$ & 25.68 & 28.28 \\
\hline 2 & Fill factor, FF (\%) & 84.11 & 84.80 \\
\hline 3 & Current (Short Circuit), $\mathrm{J}_{\mathrm{SC}}\left(\mathrm{mA} / \mathrm{cm}^{2}\right)$ & 25.33 & 23.472 \\
\hline
\end{tabular}




\begin{tabular}{|l|l|c|c|}
\hline 4 & Voltage (Open Circuit), $\mathrm{V}_{\mathrm{OC}}(\mathrm{V})$ & 1.21 & 1.4207 \\
\hline
\end{tabular}
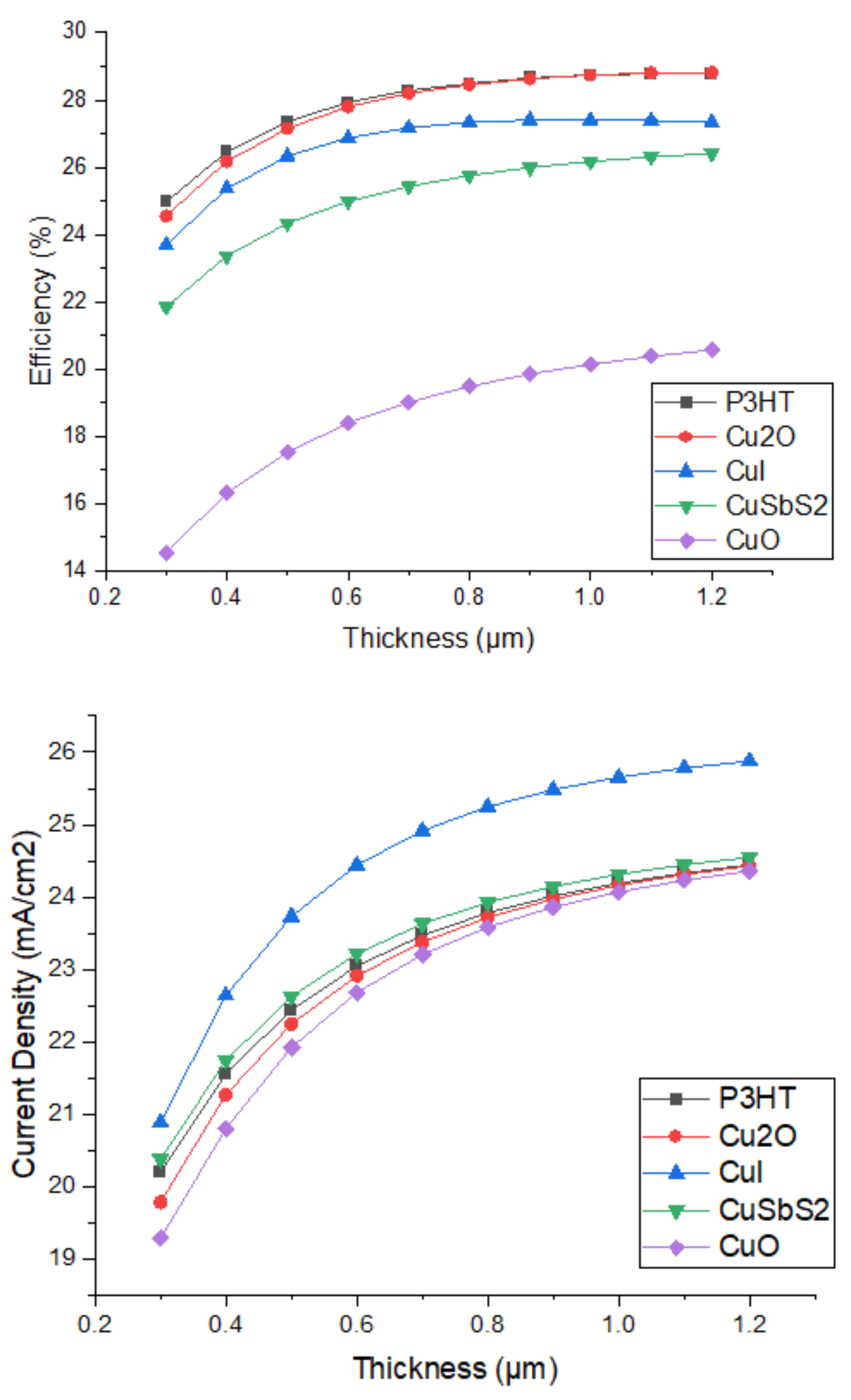

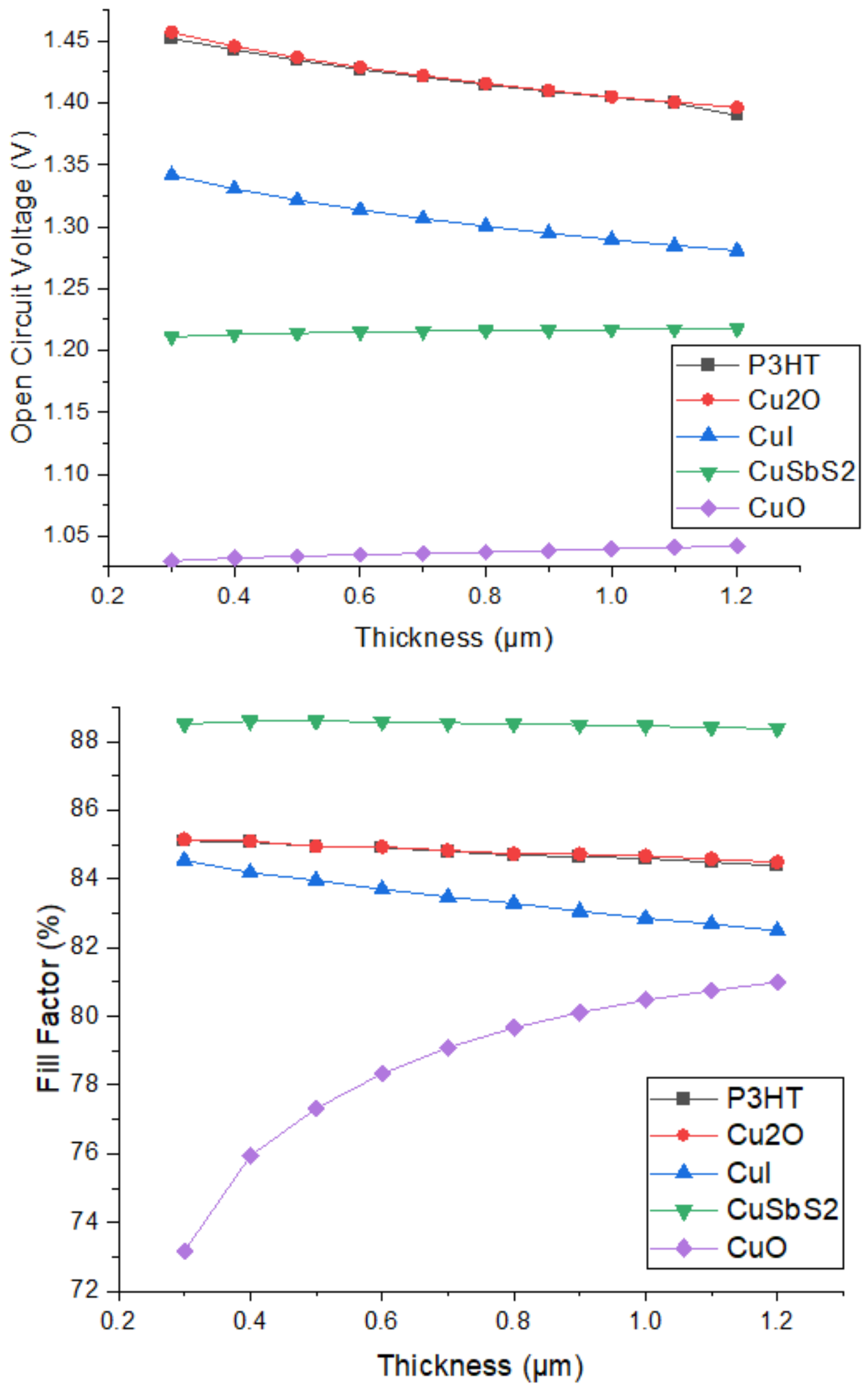

Fig.3. Graphical representation of cell parameters of existing [21] and proposed device w.r.t varying thickness of active layer

Impact of Total Defect Density (Defect Concentration) in Mixed Halide Perovskite 
Defect density is a significant factor that plays a very crucial role in determining the performance of perovskite solar cell. The photo generated charge carriers produced in perovskite layer gets parted way under the effect of electric field and migrate towards corresponding ETL and HTL. The quality of mixed halide perovskite layer straightway influences the device performance which can be disrupted view substantial amount of defects existed in the layer. These existing defects result in early recombination of holes and electrons therefore restricting their active involvement. Further, Gaussian defect states have greater influence on hole and electrons trapping than that of Urbach tail which finally influences the cell performance [26]. The variations in various device parameters by varying total defect density is represented through graphs in Fig.4. From the graphs, it is seen that there is decline in cell parameters - defect density curves in the range of $10^{8}-10^{15} \mathrm{~cm}^{-3}$. The device is extremely efficacious at the least defect density value of $10^{8} \mathrm{~cm}^{-3}$ which indicates the fineness of perovskite layer with minimum defects [22, 27-29]. Nonetheless, it is herculean task to synthesize such a fine, smooth and immaculate surface. The existing solar device with $\mathrm{CH}_{3} \mathrm{NH}_{3} \mathrm{PbI}_{3-\mathrm{XCl}}$ as perovskite layer exhibits optimized value of device parameters (Power Conversion Efficiency $=25.58 \%$, Fill Factor $=84.11 \%$, Short Circuit Current $=25.33 \mathrm{~mA} / \mathrm{cm}^{2}$ ) with defect density $10^{13} \mathrm{~cm}^{-3}[21]$. In comparison to existing one, the proposed device with defect density $10^{12} \mathrm{~cm}^{-3}$ in mixed halide perovskite i.e. $\mathrm{CH}_{3} \mathrm{NH}_{3} \mathrm{~Pb}\left(\mathrm{I}_{1-\mathrm{x}} \mathrm{Br}_{\mathrm{x}}\right)_{3}$, the optimized values of various parameters achieved using different HTLs are tabulated below in Table 3.

Table 3 Various parameters achieved using different HTLs

\begin{tabular}{|c|c|c|c|c|c|}
\hline $\begin{array}{l}\text { Sr. } \\
\text { No. }\end{array}$ & $\begin{array}{l}\text { Various HTLs used } \\
\text { separately in } \\
\text { proposed solar cells }\end{array}$ & $\begin{array}{l}\text { Efficiency }(\eta) \text {, } \\
\%\end{array}$ & $\begin{array}{l}\text { Short } \\
\text { Circuit } \\
\text { Current } \\
\left(J_{S C}\right), \\
\mathbf{m A} / \mathbf{c m}^{2}\end{array}$ & $\begin{array}{l}\text { Open Circuit } \\
\text { Voltage } \\
(\text { Voc }), \mathbf{V}\end{array}$ & $\begin{array}{l}\text { Fill factor } \\
\text { (FF), \% }\end{array}$ \\
\hline 1. & P3HT & 28.28 & 23.472 & 1.420 & 84.80 \\
\hline 2. & $\mathrm{Cu}_{2} \mathrm{O}$ & 28.20 & 23.379 & 1.422 & 84.83 \\
\hline 3. & $\mathrm{CuSbS}_{2}$ & 25.43 & 23.629 & 1.215 & 88.54 \\
\hline 4. & $\mathrm{CuO}$ & 19.02 & 23.207 & 1.035 & 79.10 \\
\hline
\end{tabular}



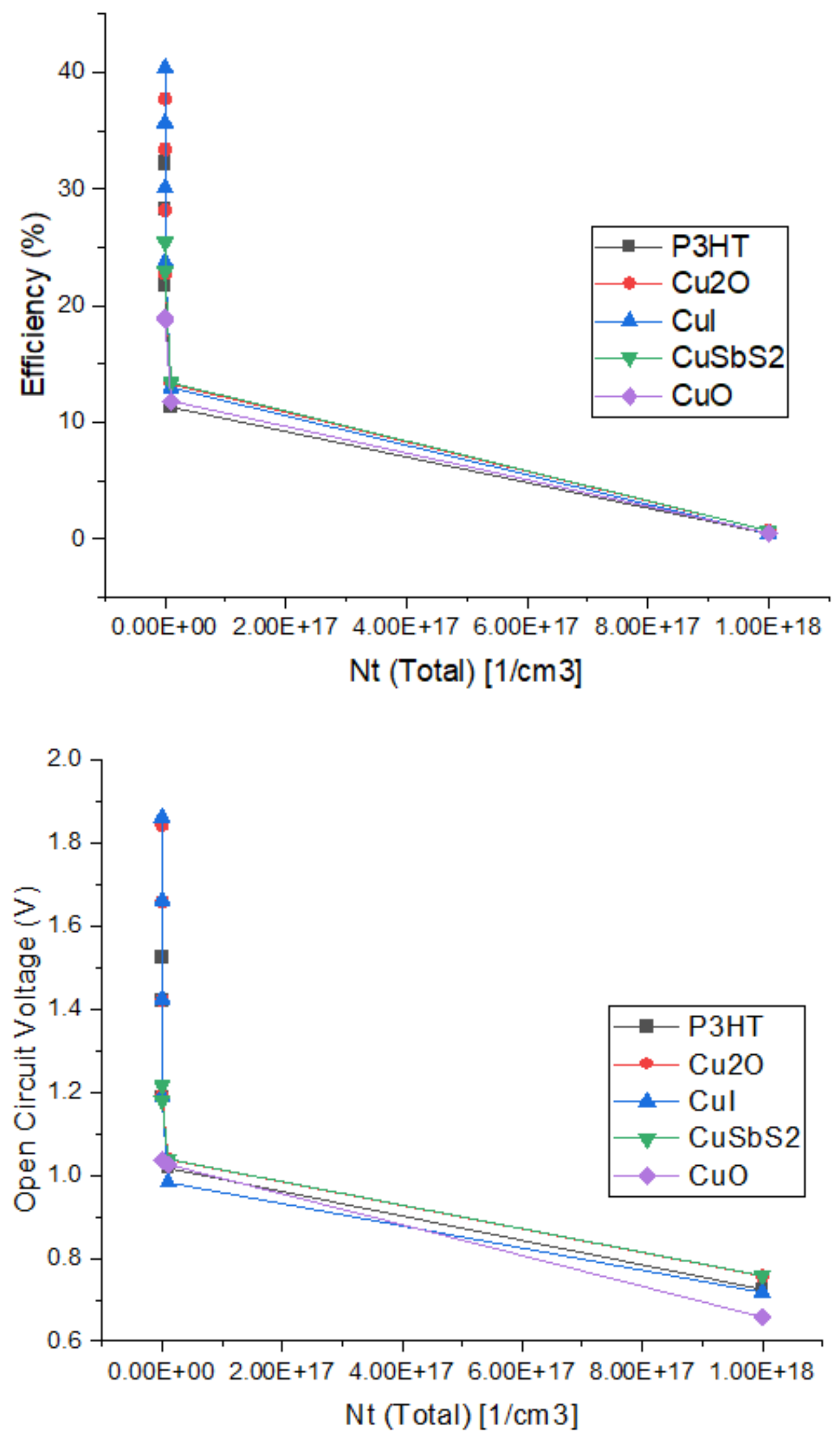

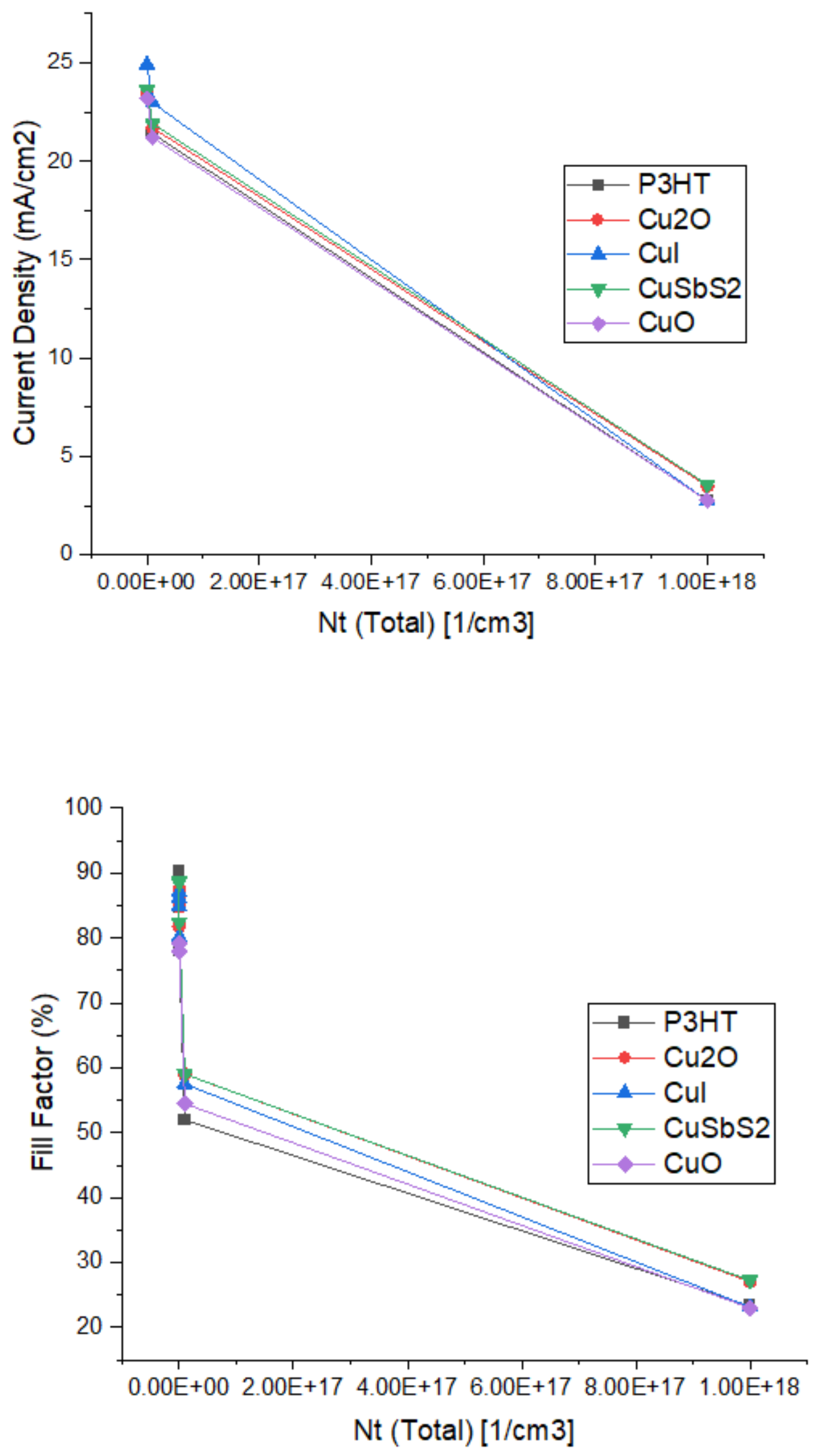
Fig.4. Graphical representation of solar cell parameters $w r t$ total defect density of active layer

\section{Effect of Donor Density of Mixed Halide Perovskite Layer}

Figure 5 demonstrates that the proposed perovskite solar cell with donor density of $10^{13} \mathrm{~cm}^{-3}$ in active layer $\mathrm{CH}_{3} \mathrm{NH}_{3} \mathrm{~Pb}\left(\mathrm{I}_{1-\mathrm{x}} \mathrm{Br}_{\mathrm{x}}\right)_{3}$ having $\mathrm{P} 3 \mathrm{HT}$ as $\mathrm{HTL}$ displays an optimized efficiency of $28.28 \%$ which is much higher than the optimized efficiency of existing solar cell, having same donor density in active layer $\mathrm{CH}_{3} \mathrm{NH}_{3} \mathrm{PbI}_{3-\mathrm{XCl}}$, including $\mathrm{CuI}$ as $\mathrm{HTL}$. The values of other device parameters of proposed solar cell are $\mathrm{Voc}=1.42 \mathrm{~V}, \mathrm{Jsc}=23.47 \mathrm{~mA} / \mathrm{cm}^{2}$ and fill factor $=84.80 \%$. Deviation in donor density straightway influences the potential of solar cell. An increment in donor density level boosts the built-in electric field which finally results lift up the device performance.

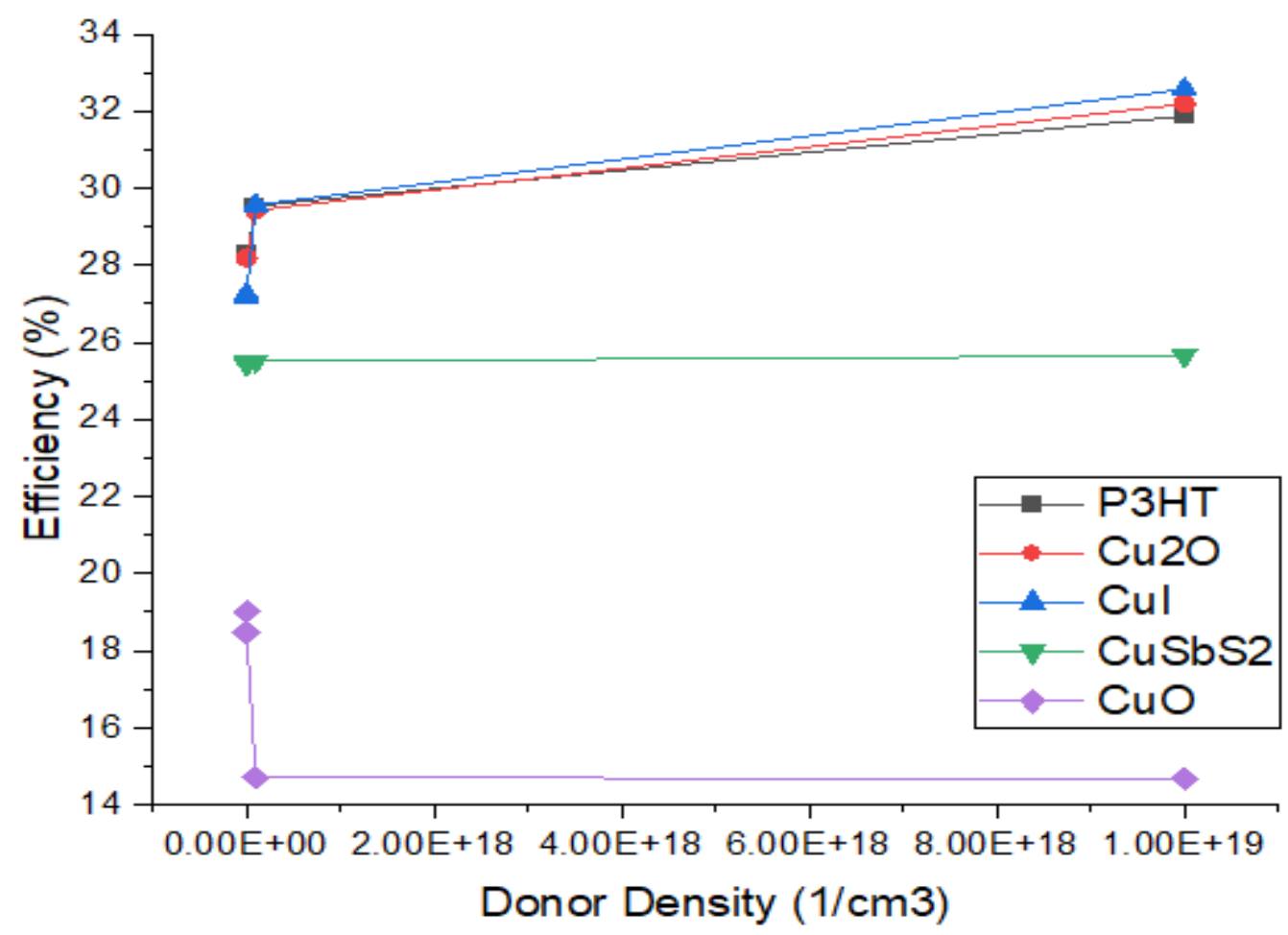



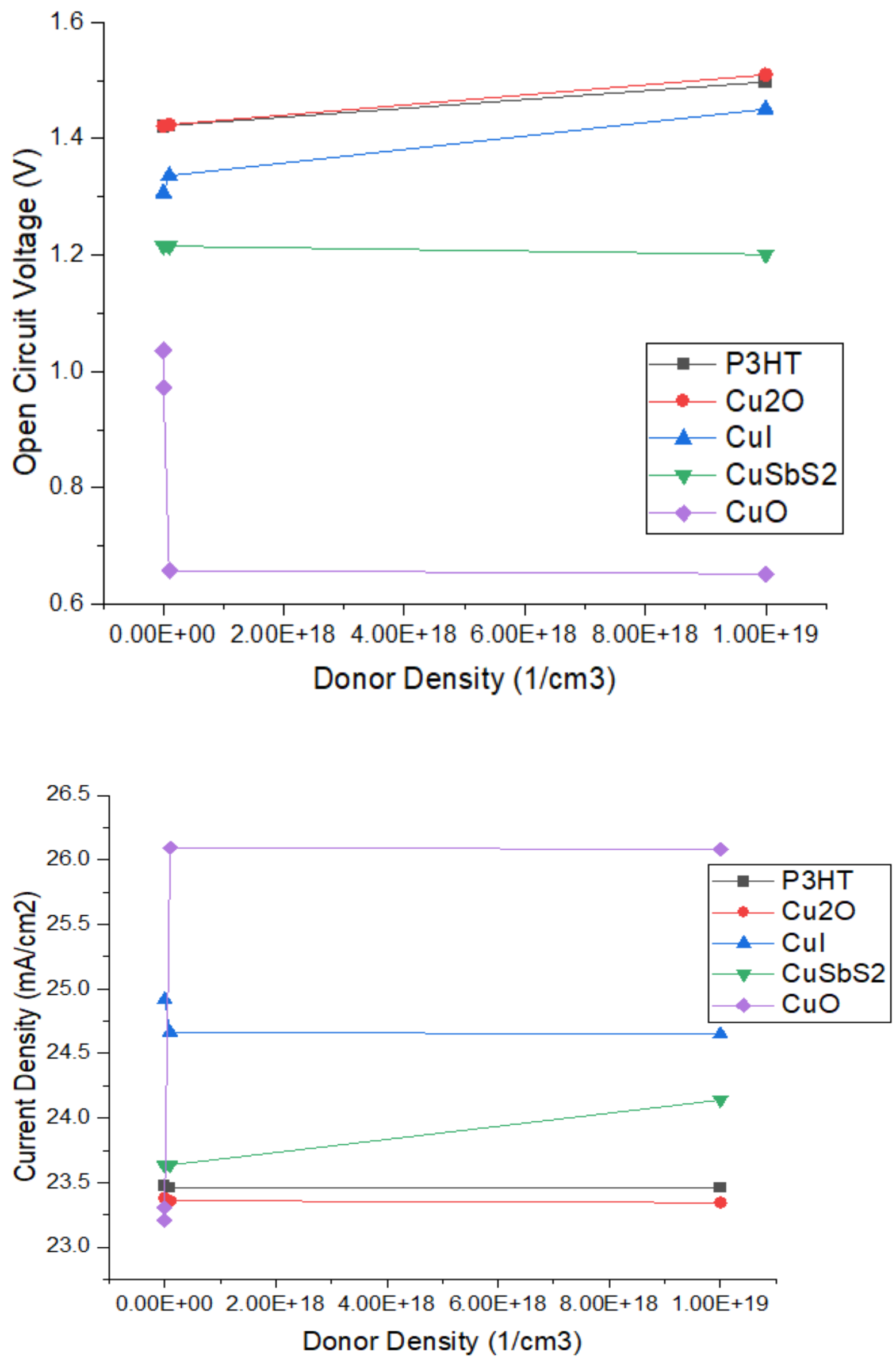


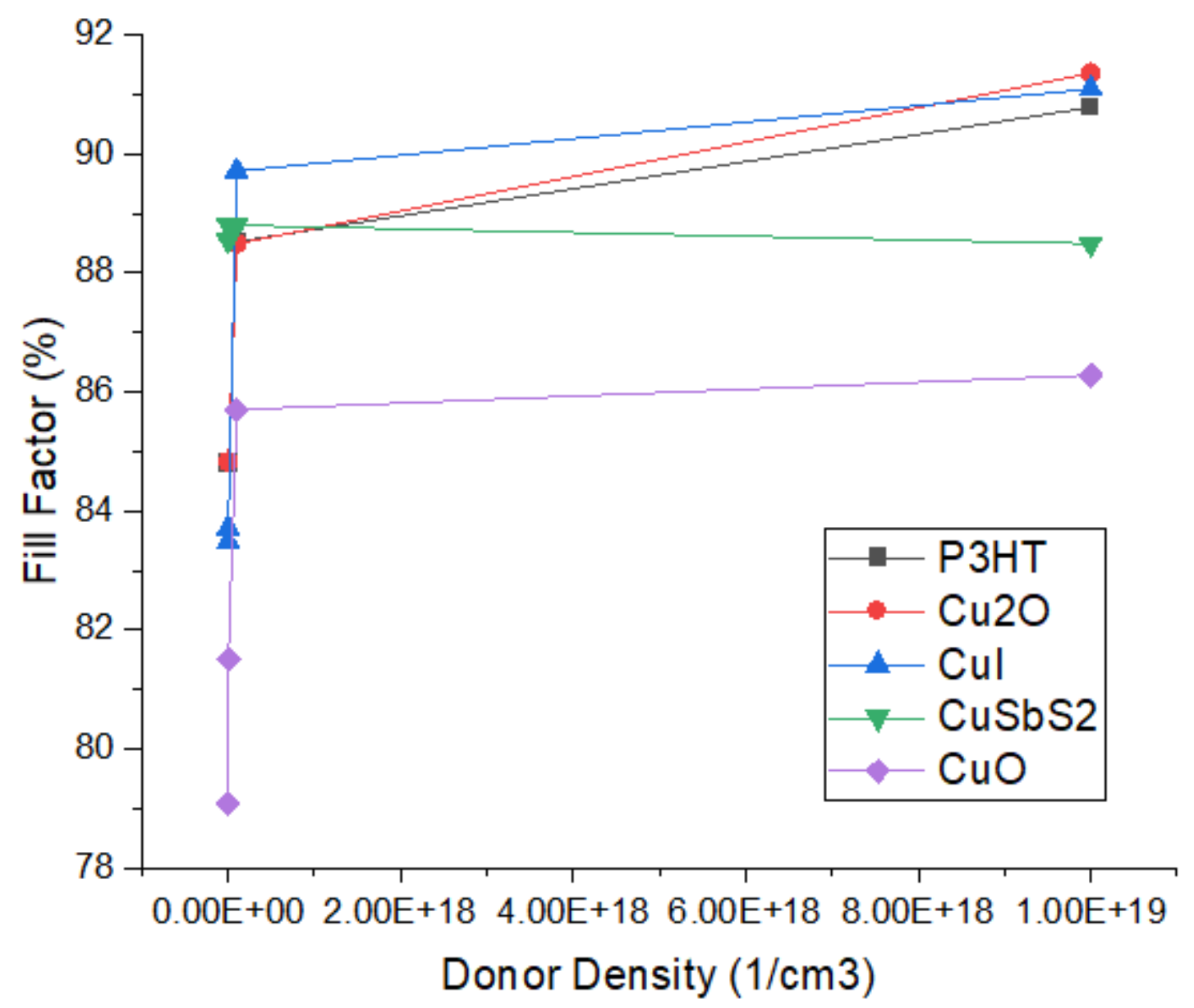

Fig.5. Graphical representation of cell parameters w.r.t donor density of active layer

\section{Effect on Recombination Rate due to Defect Density of $\mathrm{CH}_{3} \mathrm{NH}_{3} \mathrm{~Pb}\left(\mathrm{I}_{1-\mathrm{x}} \mathrm{Br}\right)_{3}$ Layer}

The influence of defect density of perovskite layer on cell operation can be easily obtained using Shockley-Read-Hall (SRH) recombination model by ascertaining the influence of defect density onto recombination rate [18-20]. Graph sought between rate of recombination and depth from surface at varying defect density is illustrated through Fig. 6. A surge in recombination rate can be observed by raising the volume of defect density. Consequently, output of solar cell parameters fall with increase in defect density as depicted through Fig. 7. 


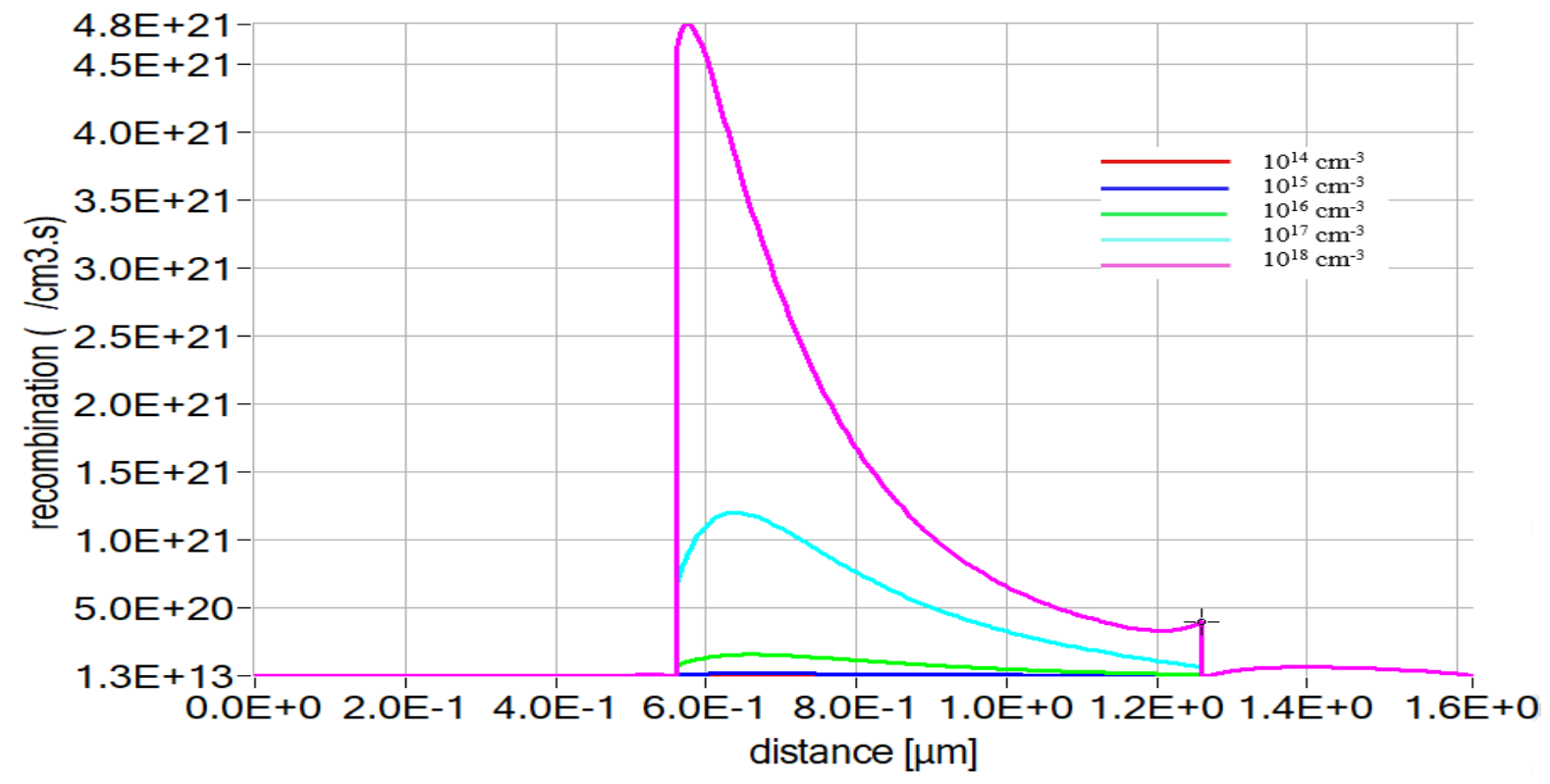

Fig. 6. Graphical representation of rate of recombination against different depths from surface w.r.t different defect densities

From equation 4 , it is seen that relaxation time of mobile charged particles is inversely proportional to defect density. Also, from equation 3, it is visible that recombination rate in inversely proportional to relaxation time of mobile charged particles. The abovementioned equations mathematically confirm that with increase in defect density, relaxation time of mobile charged particles reduces and finally recombination rate increases.

The relaxation time of charge carriers is also useful in conveying diffusion length $(l)$. From equation 5, it is confirmed that higher value of mobility of charge carriers results in larger diffusion length. Therefore, a low recombination rate and large diffusion length results in higher efficiency of $28.28 \%$. Energy diagram in respect of planned solar cell is illustrated by Fig.3.

\section{CONCLUSION}

In the last, it is summarised that with the help of SCAPS-1D simulator, optimization of perovskite solar cell with perovskite layer $\mathrm{CH}_{3} \mathrm{NH}_{3} \mathrm{~Pb}\left(\mathrm{I}_{1-x} \mathrm{Br}_{\mathrm{x}}\right)_{3}$ is exhaustively examined. The effect of different HTLs on the solar cell performance is analysed to obtain maximum efficiency. From the simulation, it has been noticed that perovskite solar cell comprising of $\mathrm{Cd}_{1-\mathrm{x}} \mathrm{Zn}_{\mathrm{x}} \mathrm{S}$ as ETL and P3HT as HTL exhibits higher efficiency than the other combinations. During simulation, effect of various properties viz doping concentration, thickness, and total defect density on perovskite layer $\mathrm{CH}_{3} \mathrm{NH}_{3} \mathrm{~Pb}\left(\mathrm{I}_{1-\mathrm{x}} \mathrm{Br}_{\mathrm{x}}\right)_{3}$ using different HTLs is investigated in order to enhance the cell performance. Interestingly, it is witnessed that alternation in HTL thickness shows negligible effect on solar cell performance. Further, doping in perovskite layer immensely influences the cell performance. This paper elaborates that the proposed perovskite solar cell with active layer $\mathrm{CH}_{3} \mathrm{NH}_{3} \mathrm{~Pb}\left(\mathrm{I}_{1-\mathrm{x}} \mathrm{Br}_{\mathrm{x}}\right)_{3}$ and $\mathrm{P} 3 \mathrm{HT}$ as HTL displays an optimized efficiency of $28.28 \%$ which is much higher than the optimized efficiency $(25.68 \%)$ of existing solar cell, having active layer $\mathrm{CH}_{3} \mathrm{NH}_{3} \mathrm{PbI}_{3-\mathrm{XCl}}$, and $\mathrm{CuI}$ as $\mathrm{HTL}$. This prototype 
of solar cell may potentially assist the researchers for subsequent investigation towards practical realisation of mixed halide perovskite solar cells.

\section{Authors contribution:}

All authors contributed equally.

\section{Funding statement:}

The authors declare that they have no funding available for the publication chargers of open access. Consider the paper as regular paper.

\section{Conflict of Interest:}

Authors declare that there is no conflict of Interest.

\section{Availability of data and material:}

Data used for the results are available in the manuscript in tabular and graphical form.

\section{Compliance with ethical standards:}

Not applicable

\section{Consent to participate:}

We here give our consent to participate and communicate paper in this journal.

\section{Consent for Publication:}

We here give our consent to publish paper in the Journal of Computational Electronics, Springer.

Acknowledgment: Research Scholar is thankful to faculty of CDC Department, Department of Electronics and Communication Engineering NITTTR Chandigarh for their interest in this work and useful comments to draft the final form of the paper. We would like to thank NITTTR Chandigarh for lab facilities and research environment to carry out this work.

\section{References}

[1] D. Sharma, R. Mehra, B. Raj (Ed.), Materials and Methods for Performance Enhancement of Perovskite Photovoltaic Solar Cells: A Review, Recent Advances in Power Systems. In: Gupta, O.H., EPREC, Springer Nature, Singapore Pte Ltd. 699 (2020) 531-542. https://doi.org/10.1007/978-981-15-7994-3_49

[2] A. Pengpad, P. Ruankham, A. Rattanachata, S. Rattanasuporn, W. Jenpiyapong, H. Nakajima, S. Choopun, V. Amornkitbamrung, Surface composition of $\mathrm{MAPb}\left(\mathrm{I}_{\mathrm{x}} \mathrm{Br}_{1-\mathrm{x}}\right)_{3}(0 \leq \mathrm{x} \leq 1)$ organic-inorganic mixed-halide perovskites, Applied Surface Science. 479 (2019) 311-317. https://doi.org/10.1016/j.apsusc.2019.02.105

[3] H. Alipour, A. Ghadimi, Optimization of lead-free perovskite solar cells in normal-structure with WO3 and water-free PEDOT: PSS composite for hole transport layer by SCAPS-1D simulation, Optical Materials. 120 (111432) (2021). https://doi.org/10.1016/j.optmat.2021.111432

[4] D. Sharma, R. Mehra, B. Raj, Methods for Integration of III-V Compound and Silicon Multijunction Solar Cell, International Conference on Emerging Technologies: AI, IoT and CPS for science and technology applications, Dept. of ECE, NITTTR Chandigarh, 6-7 Sep, 2021.

[5] P Kaur, V Pandey and B Raj, Comparative Study of Efficient Design, Control and Monitoring of Solar Power using IoT, Sensor Letter. 18 (2020) 419-426. 
[6] A. Ahmed, K. Riaz, H. Mehmood, T. Tauqeer, Z. Ahmad, Performance optimization of $\mathrm{CH}_{3} \mathrm{NH}_{3} \mathrm{~Pb}\left(\mathrm{I}_{1-\mathrm{x}} \mathrm{Br} \mathrm{r}_{\mathrm{x}}\right)_{3}$ based perovskite solar cells by comparing different ETL materials through conduction band offset engineering, Optical Materials. (2021) 1-9. https://doi.org/10.1016/j.optmat.2020.109897

[7] E. Karimi, S. Ghorashi, The Effect of $\mathrm{SnO}_{2}$ and $\mathrm{ZnO}$ on the Performance of Perovskite Solar Cells, Journal of Electronics Materials. 49(1) (2020) 364-376. https://doi.org/10.1007/s11664-019-07804-4

[8] T.H. Chowdhury, M.T. Ferdaous, M.A.A. Wadi, P. Chelvanathan, N. Amin, A. Islam, N. Kamaruddin, M.I.M. Zin, M.H. Ruslan, K.B. Sopian, M. Akhtaruzzaman, Prospects of Ternary $\mathrm{Cd}_{1-\mathrm{x}} \mathrm{Zn}_{\mathrm{x}} \mathrm{S}$ as an Electron Transport Layer and Associated Interface Defects in a Planar Lead Halide Perovskite Solar Cell via Numerical Simulation, Journal of Electronics Materials. 47 (2018) 3051-3058. https://doi.org/10.1007/s11664-018-6154-4

[9] Q. Jiang, X. Zhang, J. You, SnO2: A Wonderful Electron Transport Layer for Perovskite Solar Cells, Small. 14(31) (2018) (1801154). https://doi.org/10.1002/smll.201801154

[10] N. Rai, S. Rai, P.K. Singh, D.K. Dwivedi, Analysis of various ETL materials for an efcient perovskite solar cell by numerical simulation, Journal of Materials Science: Materials in Electronics. 27(4) (2020). https://doi.org/10.1007/s10854-020-04175-Z

[11] M. Shasti, A. Mortezaali, Numerical Study of $\mathrm{Cu}_{2} \mathrm{O}, \mathrm{SrCu}_{2} \mathrm{O}_{2}$, and $\mathrm{CuAlO}_{2}$ as Hole Transport Materials for Application in Perovskite Solar Cells, Phys. Status Solidi A. (1900337) (2019) 1-10. https://doi.org/10.1002/pssa.201900337

[12] F.D. Rossi, G. Renno, B. Taheri, N.Y. Nila, V.Illieva, A. Fin, A.D. Carlo, M. Bonomo, C. Barolo, F. Brunetti, Modified P3HT materials as hole transport layers for flexible perovskite solar cells, Journal of Power Sources. 494 (2021) 229735. https://doi.org/10.1016/j.jpowsour.2021.229735

[13] S. Li, Y.L. Cao, W.H. Li, Z.S. Bo, A brief review of hole transporting materials commonly used in perovskite solar cells, Rare Metals. 40(10) (2021) 2712-2729. https://doi.org/10.1007/s12598-020-01691-Z

[14] A. Kojima, K. Teshima, Y. Shirai, T. Miyasaka, Organometal halide perovskites as visible-light sensitizers for photovoltaic cells, J. Am. Chem. Soc. 131 (17) (2009) 6050-6051. https://doi.org/10.1021/ja809598r

[15] National Renewable Energy Laboratory, Best research-cell efficiencies. https://www.nrel.gov/pv/assets/images/best-research-cell-efficiencies.20200104.

[16] N. Gamal, S.H. Sedky, A. Shaker, M. Fedawy, Design of lead-free perovskite solar cell using $\mathrm{Zn}_{1-\mathrm{x}} \mathrm{Mg}_{\mathrm{x}} \mathrm{O}$ as ETL: SCAPS device simulation, Optik. 242 (167306) (2021). https://doi.org/10.1016/j.ijleo.2021.167306

[17] D. Sharma, R. Mehra, B. Raj, Comparative Analysis of Photovoltaic Technologies for High Efficiency Solar Cell Design, Superlattices and Microstructures. $153 \quad$ (106861) (2021) 531-542. https://doi.org/10.1016/j.spmi.2021.106861

[18] H.J. Du, W.C. Wang, J.Z. Zhu, Device simulation of lead-free $\mathrm{CH}_{3} \mathrm{NH}_{3} \mathrm{SnI}_{3}$ perovskite solar cells with high efficiency, Chin. Phys. B. 25(10) (2016) 108802. https://doi.org/10.1088/1674-1056/25/10/108802

[19] W. Shockley, W.T. Read, Statistics of the recombinations of holes and electrons, J Phys Rev. 87(5) (1952) 835-842. https://doi.org/10.1103/PhysRev.87.835

[20] P. K. Patel, Device simulation of highly efficient eco-friendly CH3NH3SnI3 perovskite solar cell, Nature portfolio. 11 (3080) (2021). https://doi.org/10.1038/s41598-021-82817-w

[21] N. Thakur, R. Mehra, C. Devi, Efficient Design of Perovskite Solar Cell Using Parametric Grading of Mixed Halide Perovskite and Copper Iodide, Journal of Electronic Materials. 47 (2018) 6935-6942. https://doi.org/10.1007/s11664-018-6620-z

[22] M.S.G. Hamed, G.T. Mola, Mixed Halide Perovskite Solar Cells: Progress and Challenges, Critical Reviews in Solid State and Materials Sciences. 45(2) (2020) 85-112. https://doi.org/10.1080/10408436.2018.1549976 
[23] K.D. Jayan, V. Sebastian, Comprehensive device modelling and performance analysis of $\mathrm{MASnI}_{3}$ based perovskite solar cells with diverse ETM, HTM and back metal contacts, Solar Energy. 217 (2021) 40-48. https://doi.org/10.1016/j.solener.2021.01.058

[24] A.K. Singh, S. Srivastava, A. Mahapatra, J.K. Baral, B. Pradhan, Performance optimization of lead free$\mathrm{MASnI}_{3}$ based solar cell with 27\% efficiency by numerical simulation, Optical Materials. 117 (111193) (2021) https://doi.org/10.1016/j.optmat.2021.111193

[25] R. Teimouri, R. Mohammadpour, Potential application of $\mathrm{CuSbS}_{2}$ as the hole transport material in perovskite solar cell: A simulation study, Superlattices and Microstructures. 118 (2018) 116-122. https://doi.org/10.1016/j.spmi.2018.03.079

[26] V.R. Akshay, B. Arun, G. Mandal, M. Vasundhara, Visible range optical absorption, Urbach energy estimation and paramagnetic response in $\mathrm{Cr}$-doped $\mathrm{TiO}_{2}$ nanocrystals derived by a sol-gel method, Phys. Chem. Chem. Phys. 21 (2019) 12991-13004. https://doi.org/10.1039/c9cp01351b

[27] C.M.S. Fella, D.W. Miller, Q.P. Ngo, E.T. Roe, F.M. Toma, I.D. Sharp, M.C. Lonergan, A. Javey, Band Tailing and Deep Defect States in $\mathrm{CH}_{3} \mathrm{NH}_{3} \mathrm{~Pb}\left(\mathrm{I}_{1-\mathrm{x}} \mathrm{Br}_{\mathrm{x}) 3}\right.$ Perovskites as Revealed by Sub-Bandgap Photocurrent, ACS Energy Lett. 2(3) (2017) 1-27. https://doi.org/10.1021/acsenergylett.6b00727

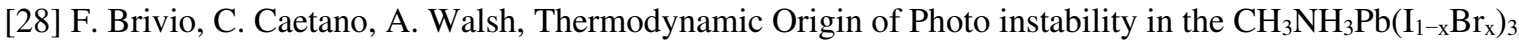
Hybrid Halide Perovskite Alloy, J. Phys. Chem. Lett. 7 (2016) 1083-1087. https://doi.org/10.1021/acs.jpclett.6b00226

[29] M.S.G. Hamed, G.T. Mola, Mixed Halide Perovskite Solar Cells: Progress and Challenges, Critical Reviews in Solid State and Materials Sciences. 45(2) (2020) 85-112. https://doi.org/10.1080/10408436.2018.1549976 